\title{
HAK RAKYAT DALAM MEKANISME PEMBUBARAN PARTAI POLITIK DI INDONESIA
}

\author{
Gema Perdana \\ Program Studi Magister Ilmu Hukum Universitas Indonesia \\ J1. Salemba Raya No. 4 Jakarta \\ Email:gema.perdana93@gmail.com
}

\begin{abstract}
: this paper aims to reveal the granting of authority to the people in the mechanism of dissolution of political parties and the idea of the Ius Constituendum mechanism of dissolution of political parties in Indonesia. This paper uses a normative juridical study with a historical approach, a case approach, and a statute approach. This paper shows that the granting of authority to the people in the mechanism of dissolution of Political Parties must pay attention to the people as the owner of the country's sovereignty. The people should be qualified for having legal standing in the request to dissolve political parties. Ius Constituendum the dissolution of political parties in Indonesia becomes a model of appropriate sanctions against political parties that have violated the provisions which are proven and decided by the competent institution, in this case, the judicial institution.
\end{abstract}

Keywords: people, dissolution, political party

\begin{abstract}
Abstrak: tulisan ini bertujuan untuk mengungkapkan tentang pemberian kewenangan kepada rakyat dalam mekanisme pembubaran partai politik dan gagasan ius constituendum mekanisme pembubaran partai politik di Indonesia. Tulisan ini menggunakan kajian yuridis normatif dengan pendekatan sejarah (historical approach), pendekatan kasus (case approach) dan peraturan perundang-undangan (statute appoarch). Tulisan ini menunjukkan bahwa pemberian kewenangan kepada rakyat dalam mekanisme pembubaran Partai Politik harus memperhatikan rakyat sebagai pemilik kedaulatan negara. Rakyat sudah selayaknya dapat dikualifikasian sebagai pihak-pihak yang memiliki legal standing permohonan pembubaran partai politik. Ius Constituendum pembubaran partai politik di Indonesia menjadi sebuah model sanksi yang sesuai terhadap partai politik yang dibuktikan dan diputuskan oleh lembaga yang berwenang dalam hal ini lembaga yudisial bahwa partai politik telah melanggar ketentuan.
\end{abstract}

Kata Kunci: rakyat, mekanisme, pembubaran, partai politik

\section{PENDAHULUAN}

Semangat reformasi saat ini sudah memasuki tahun ke-21 dengan adanya suatu sistem demokrasi yang dianggap sebagai sistem penyelenggaraan kekuasaan negara yang paling tepat (Manan, 2011:63). menyatakan bahwa negara yang demokratis adalah negara yang menempatkan kekuasaan tertinggi pada Rakyat. Dalam rangka membangun kehidupan berbangsa dan bernegara akan dihadapkan pada berbagai bentuk ancaman, hambatan, dan tantangan yang harus dituntaskan baik yang berasal dari dalam maupun luar sehingga dibutuhkan keuletan dan ketangguhan agar dapat mendukung pengembangan ketahanan nasional (Usman, 2003:92-101).

Pada perkara politik yang utamanya berkaitan dengan kekuasaan, keberadaannya mengubah hubungan antara rakyat dengan penguasa. Hubungan semula mendiskualifikasi rakyat dari panggung kekuasaan politik menjadi memposisikan rakyat sebagai actor dan poros penting dalam relasi itu. Perubahan tersebut bahkan berada pada sistem negara demokrasi kontemporer, keberadaan partai politik telah menjadi 
instrument utama untuk berkompetisi dan mendapatkan kendali atas institusi-instutusi politik (Pamungkas, 2012:3). Maka dari itu, keberadaan partai politik dijadikan sebagai cermin dari kebebasan berserikat (freedom of association) dan berkumpul (freedom of assembly) sebagai wujud adanya kemerdekaan berfikir (freedom of thought) serta kebebasan berekspresi (freedom of expression) yang mana kedudukannya diatur pada konstitusi negara demokrasi (Shaleh, 2011:7).

Pada pasca reformasi, salah satu dinamika yang menjadi pokok perhatian ialah demokratisasi politik yang ditandai dengan lahir dan menguatnya peranan partai politik dalam kehidupan bernegara. Banyak pihak mendirikan partai politik salah satunya dengan tujuan untuk mendapatkan kedudukan dalam pemerintahan, sehingga bila dimungkinkan jika sebuah partai politik yang keluar dari tujuan utama dapat dibubarkan. Sebagai negara demokrasi, peran partai politik saat ini dan di masa yang akan datang akan semakin penting dalam kehidupan berbangsa dan bernegara, hal ini karena negara demokrasi memang dibangun di atas sistem kepartaian (Laski, 1951:312). Menurut Assiddiqie (2010:272), partai politik sebagai wadah perwujudan kebebasan berserikat dan berkumpul yang dijamin oleh konstitusi tidak secara otomatis bersifat bebas tanpa batas, namun terdapat batasan-batasan yang diperlukan dalam masyarakat demokratis demi menjaga keamanan dan keselamatan nasional, mencegah terjadinya potensi kejahatan dan untuk melindungi hak-hak dan kebebasan lainnya.

Pembatasan tersebut juga merupakan bentuk pengawasan terhadap partai politik sebagai sebuah konsekuensi atas prinsip negara hukum yang dianut oleh suatu negara, termasuk oleh negara Republik Indonesia. Supaya tidak memberangus kebebasan berserikat, pembatasan itu harus dilakukan secara ketat yang, meliputi (1) pembatasan harus diatur dalam aturan hukum, (2) dilakukan semata-mata untuk mencapat tujuan dalam masyarakat demokratis, dan (3) memang benar-benar dibutuhkan dan bersifat proporsional sesuai dengan kebutuhan sosial. Semakin berkembangnya kehidupan politik dan partai politik, maka dari membutuhkan adanya pengaturan dari berbagai aspek. Keberadaan partai politik memang merupakan manifestasi dari hak atas kebebasan berserikat dan berkumpul serta hak menyatakan pendapat. Hak kebebasan tersebut dapat dibatasi dengan melakukan pengaturan termasuk melakukan pembubaran partai politik.

Di Indonesia pelaksanaan fungsi pengawasan terhadap partai politik dilakukan setidaknya melalu dua hal, yaitu melalui pelaksanaan pemilihan umum setiap lima tahun sekali dan melalui pembubaran partai politik. Pada Pasal 25C ayat (1) UUD NRI Tahun 1945 salah satunya memberikan kewenangan kepada Mahkamah Konstitusi untuk dapat membubarkan partai politik. Terdapat beberapa alasan yang dapat dijadikan dasar untuk dapat membubarkan partai politik diantaranya ialah Partai Politik telah terbukti melakukan kegiatan yang bertentangan dengan Pancasila, UUD NRI Tahun 1945, menganggu NKRI dan terbukti menyebarkan faham komunisme dan leninisme.

Hal tersebut dianggap terlalu dangkal, sehingga sulit untuk diterapkan. Karena saat ini bentuk pelanggaran yang dilakukan dapat dilakukan secara teknis dan detail. Sebagai contoh adalah partai politik yang terbukti melakukan pelanggaran pemilu yang sifatnya terstruktur, sistematis dan masif, kemudian jika partai politik pemegang kekuasaan pemerintahan menggunakan kewenangan yang dimiliki untuk kepentingan partai politik mendapatkan keuntungan. Tentu saja hal-hal teknis tersebut tidak diatur unsur-unsur yang dipersyaratkan untuk membubarkan partai politik.

Perkara lain yang menjadi pokok 
perhatian selanjutnya ialah pihak yang dapat bertindak sebagai pemohonan dalam rangka mengajukan gugatan pembubaran partai politik pada Mahkamah Konstitusi yang hanya dapat diwakilkan oleh Pemerintah Pusat yaitu Menteri Hukum ataupun Jaksa Agung. Keputusan tersebut diatur pada Pasal 68 ayat (1) UU No. 24 Tahun 2003 tentang Mahkamah Konstitusi jo Pasal 3 ayat (1) PMK No. 12 Tahun 2008. Hal ini menjadi semakin mustahil untuk dilakukan fungsi kontrol dan pengawasan terhadap partai politik karena peran tunggal yang diberikan kewenangan untuk menjadi pemohon yaitu pemerintah.

Partai politik yang sedang berkuasa di pemerintahan menyalahgunakan kekuasaan yang dimilikinya. Kekuasan tersebut dengan disalahgunakan untuk menghalangi lawan politik dengan menggunakan dalil dapat mengajukan permohonan pembubaran partai politik yang menjadi lawan dalam parlemen atau yang bersebrangan dengan aliran partai politik penguasa di pemerintahan. Kemudian, partai politik yang berkuasa di pemerintah patut diduga telah melakukan sebuah tindakan yang bertentangan dengan ideologi atau UUD NRI Tahun 1945, hal ini akan menjadi conflict of interest dari pemerintah untuk dapat mengajukan permohonan pembubaran partai politik kepada MK karena yang akan digugat adalah partainya sendiri. Pembubaran partai politik makin sulit manakala tradisi politik membiasakan adanya pembentukan koalisi-koalisi untuk memerintah bersama. Maka, pembubaran partai politik berkuasa akan ditentang oleh koalisinya. Hal ini yang kemudian menjadi perhatian karena partai politik sebagai representasi implementasi kebebasan berserikat dan berkumpul tidak berjalan dengan bebas tanpa batas dan pengawasan. Adanya monopoli dalam legal standing pembubaran partai politik ini jelas menutup pihak lain untuk mengajukan permohonan ke Mahkamah Konstitusi, sebagai contoh adalah warga negara. Tumpulnya implikasi peran warga negara dalam mengawasi kinerja partai politik, padahal dalam negara yang demokratis peran warga negara sebagai pemegang kedaulatan tertinggi sangatlah strategis. Apalagi dalam hal pengawasan partai politik yang merupakan asal seorang wakil rakyat di pemerintahan.

Pada perkara tersebut, oleh karena itu diperlukan adanya sebuah perluasan para pihak yang dapat melakukan fungsi pengawasan dan kontrol terhadap partai politik, utamanya pada warga Negara karena partai politik menerima pendapatan dari APBN yang bersumber dari pajak rakyat. Keberadaan partai politik tidak hanya ditujukan bagi presiden, akan tetapi presiden adalah keluaran dari partai politik sehingga dirasa sangat sukar untuk secara realistis seorang presiden akan memperkarakan partai politik dan/atau koalisnya. Jadi, penting adanya perluasan pemberian hak konstitusional bagi warga negara untuk dapat mengusulkan pembubaran partai politik yang merugikan negara. Berdasarkan latar belakang persoalan tersebut, maka penulis ingin menganalisis dan mengungkapkan tentang pemberian kewenangan kepada rakyat dalam mekanisme pembubaran partai politik dan gagasan ius constituendum mekanisme pembubaran partai politik di Indonesia.

\section{METODE}

Tulisan ini menggunakan metode yuridis normatif dengan pendekatan sejarah (historical approach), pendekatan kasus (Cases approach), dan peraturan perundangundangan (statue approach). Penggunaan metode tersebut dikarenakan objek kajian dalam tulisan ini berhubungan dengan sejarah pengaturan dan eksistensi partai politik; keadaan dan realita di masyarakat; dan pengaturan partai politik secara perundangundangan di Indonesia. Spesifikasi tulisan ini bersifat diskriptif analitys karena akan banyak memberikan pembahasan terkait pendapat-pendapat pakar hukum, studi 
kasus di masyarakat serta secara peraturan perundang-undangan. Data yang digunakan ialah data sekunder yang diperoleh dari bahan-bahan pustaka yang disusun secara sistematis dan dianalisa secara kualitatif untuk menghasilkan format ideal partisipasi rakyat sebagai pihak dalam mekanisme pembubaran partai politik di Indonesia.

\section{HASIL DAN PEMBAHASAN \\ Pemberian Kewenangan Kepada Rakyat dalam Mekanisme Pembubaran Partai Politik}

\section{Eksistensi Partai Politik di Indonesia}

Partai Politik merupakan salah satu bentuk pengelompokkan warga negara berdasarkan kesamaan pikiran dan kepentingan politik. Pengelompokan tersebut telah terjadi sejak keberadaan lembaga perwakilan dalam struktur kekuasaan negara. Namun, partai politik sebagai organisasi yang terstruktur baru muncul pada 1830 sebagai wujud perkembangan demokrasi modern yang disebut dengan demokrasi perwakilan. Perkembangan demokrasi telah meningkatkan partisipasi politik masyarakat dalam kehidupan bernegara. Saranan kelembagaan terpenting yang harus dimiliki untuk mengorganisir perluasan peran serta politik tersebut adalah partai politik (Huntington, 2003:472).

Partai Politik merupakan suatu kelompok yang teroganisir di mana anggotanya mempunyai orientasi, nilai-nilai, dan cita-cita yang sama. Tujuan kelompok ini ialah untuk memperoleh kekuasaan politik dan merebut kedudukan politik (biasanya) dengan cara konstitusional untuk melaksanakan kebijaksanaan mereka (Budiarjo, 1985:160-161). Pada Pasal 1 angka (1) UU No. 2 tahun 2011 tentang perubahan atas UU No. 2 tahun 2008 tentang partai politik menyatakan bahwa partai politik adalah organisasi yang bersifat nasional dan dibentuk oleh sekelompok warga negara Indonesia secara sukarela atas dasar kesamaan kehendak dan citacita untuk memperjuangkan dan membela kepentingan politik anggota, masyarakat, bangsa dan negara serta memelihara keutuhan Negara Kesatuan Republik Indonesia berdasarkan Pancasila dan Undang-Undang Dasar Negara Republik Indonesia Tahun 1945.Partai politik merupakan komponen yang sangat penting dalam sistem politik demokrasi. Oleh karena itu, mendirikan dan menjadi anggota partai politik yang secara universal diakui sebagai pilar utama demokrasi, adalah hak asasi bagi setiap orang yang dijamin oleh UUD NRI Tahun 1945.

Perkembangan partai politik di Indonesia menjadi warna dalam perkembangan demokrasi. Partai politik merupakan gambaran wajah percaturan politik nasional atau bisa dikatakan sebagai tolak ukur partisipasi politik masyarakat. Sebagai bentuk menuju perkembangan demokrasi, partai politik lahir dari berbagai aspirasi masyarakat yang berkeinginan bersatu dalam wadah kesatuan Republik Indonesia. Partai politik merupakan institusi yang menjadi penyangga bekerjanya demokrasi perwakilan.

Selama demokrasi perwakilan masih dipandang sebagai cara yang paling masuk akal untuk mewujudkan kedaulatan rakyat, maka kehadiran partai politik tidak akan terhindarkan. Partai politik telah mengubah relasi antara rakyat dengan penguasa untuk melihat seberapa jauh peran partai politik sebagai wadah penyalur aspirasi politik rakyat. Dilihat dari sejarahnya pada awal kemerdekaan, partai politik belum berperan secara optimal sebagai wadah untuk menyalurkan aspirasi politik rakyat. Hal ini terlihat dari timbulnya berbagai gejolak dan ketidakpuasan di sekelompok masyarakat yang merasa aspirasinya tidak terwadahi dalam bentuk gerakan-gerakan separatis seperti proklamasi negara islam oleh Kartosuwiryo tahun 1949, terbentuknya negara boneka yang bernuansa kedaerahan (Ananta, 2000:48). Pada fase berikutnya dalam sejarah perjalanan bangsa yaitu masa orde lama, peran partai politik sebagai wadah penyalur aspirasi politik rakyat juga belum 
terlaksana sesuai dengan yang diharapkan partai politik yang cenderung terperangkap oleh kepentingan partai atau kelompoknya masing-masing dan bukan kepentingan rakyat secara keseluruhan.

Zaman pemerintahan orde baru peran partai politik dalam kehidupan berbangsa ditata melalui UU No. 3 Tahun 1973. Partai politik yang jumlahnya cukup banyak ditata menjadi 3 kekuatan sosial politik yang terdiri dari 2 partai politik yaitu PPP dan PDI serta Golkar. Namun, penataan partai politik tersebut ternyata tidak membuat semakin berperannya partai politik sebagai wadah penyalur aspirasi politik rakyat. Partai politik yang diharapkan dapat mewadahi aspirasi politik rakyat yang terkristal menjadi kebijakan publik yang populis tidak terwujud. Hal ini terlihat dari kebijaksanaan publik yang dihasilkan pada pemerintahan orde baru ternyata kurang memperhatikan aspirasi politik rakyat dan cenderung merupakan sarana legitimasi kepentingan penguasa dan kelompok tertentu. Akibatnya pembangunan nasional tidak merata di seluruh wilayah Indonesia dan mengakibatkan ketimpangan dan kesenjangan sosial di berbagai aspek kehidupan rakyat.

Dampak yang terjadi akhirnya partai politik tidak berfungsi sebagai penyalur aspirasi politik rakyat, akan tetapi hanya ditempatkan sebagai mesin politik penguasa dan aksesoris demokrasi untuk melegitimasi kekuasaan. Era reformasi muncul sebagai gerakan korektif dan pelopor perubahan mendasar di berbagai aspek kehidupan. Melahirkan UU No. 3 Tahun 1999 tentang partai politik memungkinkan sistem multipartai kembali bermunculan. Harapan peran partai sebagai wadah penyalur aspirasi politik akan semakin baik meskipun hingga saat ini belum menunjukkan kenyataan. Hal ini terlihat dari kampanye pemilu yang masih diwarnai banyaknya partai politik yang tidak mengaktualisasikan aspirasi rakyat dalam wujud program partai yang akan diperjuangkan. Mirip dengan fenomena lama dimana yang ada hanya janji dan slogan-slogan kepentingan politik sesaat.

Era reformasi menumbuhkan partaipartai politik baru, maka pada pemilu legislatif tahun 1999 tampil 48 partai politik yang bersaing pemilu legislatif tahun 2004 tampil 24 partai politik. Jumlah partai politik peserta pemilu turun 50\% dari pemilu sebelumnya. Tetapi, pada pemilu legislatif tahun 2009 naik lagi menjadi 38 partai politik peserta pemilu yang bersaing dan pemilu legislatif 2014 tampil 12 partai politik. Nampaknya sistem multi partai memungkinkan jumlah partai politik tidak stabil, di mana partai politik baru bisa saja muncul dari adanya tuntutan perubahan dalam masyarakat. Hal ini memungkinkan proses politik berjalan kurang efisien dan efektif.

Di samping itu, hasil pemilu-pemilu legislatif era reformasi menunjukkan bahwa tidak sampai 50\% partai-partai politik peserta pemilu mampu meraih kursi di DPR RI, bahkan pemilu legislatif tahun 2009 yang pesertanya 38 partai politik, ternyata hanya ada 9 partai politik yang mampu memperoleh kursi DPR RI, yakni: Partai Demokrat (150 kursi), PDIP (95 kursi), Partai Golkar (107 kursi), PPP (37 kursi), PKB (27 kursi), PAN (43 kursi), PKS (57 kursi), Partai Gerindra (26 kursi) dan Partai Hanura (18 kursi), (KPU.RI, Laporan Hasil Pemilu Legislatif, 2009). Data ini menggambarkan betapa banyaknya "energi politik" yang terbuang tanpa mencapai sasarannya.

Meskipun demikian, pada pemilu legislatif tahun 2014, terjadi perkembangan baru yaitu dari 12 partai politik peserta pemilu ternyata ada 10 partai politik mampu meraih kursi DPR RI, yaitu PDIP (109 kursi), Golkar (91 kursi), Gerindra (73 kursi), Demokrat (61 kursi), PAN (49 kursi), PKB (47 kursi), PKS (40 kursi), PPP (39 kursi), Nasdem (35 kursi), Hanura (16 kursi); (Keputusan KPU Nomor: 416/Kpts/KPU/ Tahun 2014 tentang Penetapan Perolehan Kursi Partai Politik dan Penetapan Calon Terpilih Anggota DPR Dalam Pemilu 2014). 
Data pemilu legislatif dikemukakan di atas, menunjukkan tidak ada partai politik peserta pemilu yang mampu meraih kursi DPR RI di atas 50\% (> 50\%).Hal ini menjadikan partai politik peraih kursi DPR RI, membangun kerjasama atau koalisi dalam mengajukan calon presiden dan wakil presiden.

Keberadaan partai politik sebenarnya sangat penting sebagai fasilitator aspirasi rakyat, akan tetapi kepercayaan rakyat terhadap partai politik semakin menurun. Hal ini dikarenakan banyak anggota-anggota partai politik yang menduduki jabatan publik tidak menjalankan peran dan fungsi sebagaimana mestinya. Bahkan banyak anggota partai politik yang korupsi yang sudah pasti merugikan negara dan masyarakat. Banyaknya kerja anggota legislatif yang kurang produktif yang dibuktikan dengan rendahnya dan buruknya produk legislasi yaitu undang-undang yang dibentuk. Dari peristiwa-peristiwa tersebut banyak yang beranggapan bahwa partai politik gagal menjalankan fungsi edukasi dan kaderisasi terhadap anggotanya.

Partai Politik yang berhasil mendapatkan kursi di Dewan Perwakilan Rakyat maupun Dewan Perwakilan Rakyat Daerah berhak mendapatkan bantuan dana operasional dari negara, dimana uang tersebut berasal dari pajak yang dibayarkan oleh rakyat kepada Negara sehingga sangat wajar bahwa rakyat merasa dirugikan. Partai politik yang sebagian operasionalnya dibiayai oleh negara tidak menjalankan fungsi sebagaimana mestinya. Dalam praktiknya rakyat susah mendapatkan akses informasi dari partai politik sehingga peran rakyat dalam mengontrol eksistensi partai sangat kecil sedangkan partai adalah institusi yang dibentuk dalam rangka menjalankan fungsi aspirasi dan representasi rakyat.

\section{Hak Rakyat sebagai Pemegang Kedaulatan}

Ide dasar teori kedaulatan rakyat sangat sederhana bahwa rakyatlah yang harus menjadi sumber kekuasaan tertinggi dalam suatu negara sedangkan yang lain tidak. Rakyat berkuasa secara independent atas dirinya sendiri (Nurtjahjo, 2006:33-36). Bung Hatta mengatakan bahwa "kedaulatan rakyat berarti pemerintahan rakyat". Pemerintahan yang dilakukan oleh pemimpin-pemimpin yang dipercayai oleh rakyat (Santoso, 2009:61). Ide kedaulatan rakyat ini lahir sebagai reaksi atas teori kedaulatan raja yang kebanyakan menghasilkan monopoli dan penyimpangan kekuasaan yang akhirnya menyebabkan tirani dan kesengsaraan rakyat (Nurtjahjo, 2006:33).

Dalam berbagai literatur politik, hukum, dan teori ketatanegaraan pada zaman sekarang, terminologi kedaulatan (souvereignity) itu pada umumnya diakui sebagai konsep yang dipinjam dari bahasa latin, soverain dan superanus, yang kemudian menjadi sovereign dan sovereignity dalam bahasa Inggris yang berarti penguasa dan kekuasaan yang tertinggi (Asshiddiqie, 2006:115-116). Dalam teori kedaulatan rakyat berarti rakyatlah yang mempunyai kekuasaan yang tertinggi, rakyatlah yang menentukan corak dan cara pemerintahan, dan rakyatlah yang menentukan tujuan apa yang hendak dicapai.

John Stuart Mill menyatakan bahwa demokrasi itu dipilih bukan karena merupakan hak-hak pribadi secara apriori, melainkan karena akan meningkatkan mutu kehidupan semua orang (Revitch \& Abigail, 2005:117:118). Seiring dengan itu, Friedrich Nietsche juga pernah mengungkapkan bahwa kebudayaan demokratis merupakan hal yang perlu bagi munculnya individu yang sangat kreatif, dan hanya individu semacam itu sajalah yang pantas dikaguminya. Penekanan lebih jauh tentang pentingnya demokrasi juga muncul dari Presiden RI Ke-4 K.H. Abdurrahman Wahid, berpendapat bahwa "demokrasi menjadi suatu keharusan yang wajib dipenuhi bukan saja karena demokrasi sangat memungkinkan terbentuknya suatu pola interaksi dan relasi politik yang equel, tidak eksploitatif, tetapi demokrasi sangat 
mendukung tegaknya pluralisme bangsa. Dalam demokrasi, pluralisme tidak sematamata sebagai suatu yang human, tetapi juga karunia Allah yang bersifat permanen (sunnatullah) (Artani, 2001:148).

Robert A. Dahl dalam melihat demokrasi lebih menitik beratkan aspek kebebasan politik. Dahl mengatakan setidaknya ada lima kriteria sehingga proses pemerintahan dapat dikatakan demokratis. Lima kriteria tersebut meliputi:pertama, partisipasi yang efektif. Sebelum sebuah kebijakan digunakan negara, seluruh rakyat harus mempunyai kesempatan yang efektif untuk memberikan pandangan-pandangan mereka. Kedua, persamaan suara. Setiap rakyat harus mempunyai kesempatan yang sama dan efektif untuk memberikan suara dan seluruh suara harus dihitung sama. Ketiga, pemahaman yang cerah. Dalam hal ini setiap rakyat harus diberikan kesempatan untuk mempelajari kebijakan-kebijakan alternatif yang relevan. Keempat, pengawasan agenda. Berbagai kebijakan negara selalu terbuka untuk diubah jika rakyat menginginkannya. Kelima, pencakupan orang dewasa. Dalam hal ini, semua atau paling tidak sebagian besar orang dewasa yang menjadi penduduk tetap seharusnya memiliki hak kewarganegaraan penuh yang ditunjukkan oleh empat kriteria sebelumnya (Dahl, 2001:52:53).

Menurut John Locke, walaupun kekuasaan telah diserahkan kepada suatu organ yaitu negara, namun rakyat sebagai kesatuan politik masih dapat menyampaikan tuntutan-tuntutan dan meminta perhatian terhadap pelanggaran yang terjadi. Untuk membentuk suatu masyarakat politik, dibuatlah undang-undang atau hukum. Hukum yang dibuat sebagai dasar keberadaan negara tersebut harus secara demokratis yaitu sesuai dengan tuntutan masyarakat.

Proses menjalankan fungsi pemerintahan untuk menjembatani antara pemerintah dan rakyat diperlukan adanya partai politik. Pembuatan keputusan secara teratur hanya mungkin dilakukan dengan adanya pengelompokan-pengelompokan berdasarkan tujuan-tujuan kehidupan berbangsa dan bernegara. Tugas partai politik adalah menata aspirasi rakyat yang seringkali samar-samar dan berbeda-beda, dijadikan "pendapat umum" yang lebih mendasar sehingga dapat menjadi bahan pembuatan keputusan yang teratur. Pada negara modern yang menganut sistem Demokrasi, jumlah pemilihnya sangat besar dan kepentingannya sangat bervariasi sehingga perlu dikelola untuk menjadi suatu keputusan. Partai politik yang memilih prinsip-prinsip aspirasi para pemilih yang akan diterjemahkan dalam proses legislasi.

Partai Politik memainkan peran yang menentukan dalam sebuah sistem demokrasi modern dan merupakan pilar utama dalam pranata sistem politik. Parpol menerjemahkan nilai dan kepentingan suatu masyarakat dalam proses dari bawah ke atas, sehingga nilai dan kepentingan dari masyarakat sebagai pemegang kedaulatan tertinggi dapat diakomodir melalui fungsi partai politik sebagai jembatan antara negara dan rakyat. Karena partai politik sangat penting untuk menjamin perkembangan dan pertumbuhan iklim Demokrasi, maka di banyak negara terdapat pendanaan publik yang berasal dari pajak rakyat.

Kebijakan penyaluran pendanaan tersebut diatur dan dibatasi oleh peraturan perundang-undangan yang tegas. Hal ini dimaksudkan supaya publik dapat ikut serta melakukan fungsi kontrol dan pengawasan terhadap pemanfaatannya. Masyarakat bisa ikut meningkatkan transparansi dalam perilaku serta kinerja sehingga tahu kepada kepentingan siapa partai politik berpihak, dengan demikian kualitas demokrasi dalam suatu proses politik bias menjadi semakin baik.

Hal ini menjadi sangat wajar dan menjadi hak konstitusional yang melekat bagi masyarakat sebagai pemegang kedaultan yang telah memberikan kewenangan untuk menjadi wakil rakyat melalui partai politik 
menjalankan fungsi pengawasan dan kontrol. Sehingga Partai Politik dan anggotanya sudah menjadi keharusan bahwa dalam menjalankan fungsi selalu mengedepankan kepentingan rakyat dan berlandaskan pada ideologi dan konstitusi serta peraturan perundang-undangan yang berlaku di Indonesia.

Menjadi hal yang patut untuk dipertanyakan apabila hanya satu pihak yang memiliki legal standing atau kedudukan hukum dalam pengajuan pembubaran partai politik, sama halnya pemerintah memonopoli hak tersebut dan mengabaikan keberadaan masyarakat yang juga memiliki hak untuk berpendapat atau mengeluarkan suaranya. Selain alasan pembubaran partai politik, Undang-Undang Nomor 24 Tahun 2003 juga mengatur hukum acara perkara pembubaran partai politik ditentukan bahwa yang menjadi pemohon adalah pemerintah, yaitu Pemerintah Pusat. Pemerintah sebagai pemohon juga dapat diwakili oleh instansi lain namun dengan perintah presiden seperti Jaksa Agung atau menteri yang ditunjuk oleh presiden.

Pendapat berbedan disampaikan oleh Jimly Asshiddiqie (2006:114), apabila hak pengajuan pembubaran diberikan kepada pihak lain, termasuk partai politik, berarti partai politik dibenarkan menuntut pembubaran saingannya sendiri. Hal itu harus dihindarkan karena dalam demokrasi seharusnya sesama partai politik harus bersaing secara sehat. Oleh karena itu, partai politik tidak boleh diberikan kedudukan sebagai pemohon dalam perkara pembubaran partai politik pemerintah juga berketetapan bahwa pembubaran partai politik itu dilakukan atau memang lazimnya dilakukan oleh pemerintah adalah dalam rangka memberikan perlindungan agar partai politik atau badan hukum, baik yayasan, perseroan terbatas, maupun perkumpulan yang telah memperoleh badan hukum, tidak dilakukan atau memperoleh perlindungan, dan tidak melakukan pembubaran oleh pihak lain secara semena-mena atas dasar apapun.
Pemerintah adalah badan hukum yang diakui negara dan merupakan badan hukum publik yang memiliki kewenangan terhadap partai politik, serta partai politik yang menjadi badan hukum publik. Namun perseorangan atau kelompok masyarakat bukanlah badan publik layaknya pemerintah dan partai politik. Tapi bukan berarti perseorangan atau kelompok masyarakat tidak dapat mengajukan pembubaran partai politik seperti pemerintah. Hal ini dikarenakan rakyat melihat dan merasakan dampak langsung terhadap pelanggaran yang dilakukan oleh partai politik. Masyarakat memiliki hak dan peran besar terhadap perkembangan perpolitikan di Indonesia, Masyarakat juga harus menjadi pihak yang dapat mengawasi perkembangan dan pergerakan partai politik. Undang-undang Dasar Republik Indonesia Tahun 1945 juga telah memberikan kepada rakyat untuk dapat memberikan pendapat dan suaranya terhadap pemerintahan termasuk juga unsur- unsur didalamnya yang salah satunya adalah partai politik.

Ketentuan Pasal 1 ayat (2) UUD 1945 menyatakan bahwa "Kedaulatan berada di tangan rakyat dan dilaksanakan menurut Undang-Undang Dasar". Hal ini menunjukkan bahwa rakyat diposisikan sebagai pemilik kekuasaan tertinggi di Indonesia. Pemilik kekuasaan tertinggi yang sesungguhnya di negara Indonesia adalah rakyat. Kekuasaan itu harus disadari berasal dari rakyat, oleh rakyat dan untuk rakyat. Bahkan kekuasaan hendaklah diselenggarakan bersama-sama dengan rakyat (Asshiddiqie, 2006:58).

Pemberian legal standing untuk warga negara sebagai pemohon perkara pembubaran partai politik adalah dalam rangka menerjemahkan pelaksanaan kedaulatan rakyat dan prinsip negara hukum. Sebagai pelaksanaan kedaulatan rakyat pemberian legal standing sangat penting karena pada dasarnya partai politik itu berdiri atas kebutuhan rakyat. Jika tujuan dan aktivitas partai politik itu sudah melenceng dan tak sesuai lagi dengan kehendak rakyat 
bahkan melanggar peraturan perundangundangan yang berlaku, maka rakyat harus mengevaluasinya. Pemberian legal standing tersebut adalah bagian dari cara mengevaluasi partai politik. Jika eksistensi partai politik membahayakan negara maka seharusnya rakyat diberikan hak untuk mengusulkan pembubaran partai politik sebagaimana dia punya hak untuk mendirikan partai politik.

Salah satu yang dapat dilihat bahwa pemohon pengajuan perkara pembubaran partai politik ada yang dapat diajukan oleh setiap orang, yaitu Negara Slovenia. Setiap orang berhak mengajukan inisiatif permohonan pembubaran partai politik sebagaimana tertuang dalam Bab VIII Article 68 Paragraph 1 The Constitutional Court Act Slovenia. Jika dibandingkan dengan Indonesia, sebenarnya pemohon pengajuan pembubaran partai politik di Slovenia cocok diterapkan di Indonesia. Dilihat dari persamaannya, bahwa Kepala Negara Slovenia dijabat oleh seorang Presiden dengan masa jabatan 5 tahun yang terpilih melalui pemilihan umum, dan dalam perkara pembubaran partai politik yang berwenang untuk membubarkan partai politik ialah Mahkamah Konstitusi. Pemberian legal standing pemohon pembubaran partai politik di Indonesia juga dapat diterapkan oleh setiap warga negara dan tidak hanya pemerintah saja. Hal ini bertujuan agar Warga Negara Indonesia juga dapat berperan untuk mengontrol partai politik.

\section{Pembubaran Partai Politik sebagai Kontrol Perlindungan Hak Rakyat dan Negara}

Kebebasan berserikat sebagai hak asasi manusia memiliki batasan yang diperlukan dalam masyarakat demokratis demi keamanan nasional dan keselamatan public, untuk mencegah kejahatan, serta untuk melindungi kesehatan dan moral, serta untuk melindungi hak dan kebebasan lain (Barnett, 2004:589). Pembatasan yang dibutuhkan dalam masyarakat demokratis merupakan garis apresiasi yang menyeimbangkan antara kepentingan publik dan privat. Pembatasan itu harus dimaknai secara ketat yang meliputi: bahwa pembatasan harus diatur dalam aturan hukum; harus dilakukan semata-mata untuk mencapai tujuan dalam masyarakat demokratis; dan harus memang benar-benar dibutuhkan dan bersifat proporsional sesuai dengan kebutuhan sosial (Symonides, 2000:91-92).

Perkembangan partai politik di Indonesia mengalami pasang surut seiring dengan dinamika politik dan ketatanegaraan yang berubah. Perkembangan partai politik tersebut dapat dilihat dari sisi jumlah partai politik maupun ideologi partai. Berkenaan dengan jumlah partai politik, secara kuantitatif, jumlah partai politik peserta pemilu di era reformasi selalu berubah-ubah, tidak seperti pada Orde Baru yang selalu diikuti oleh 3 partai politik, yaitu PPP, GOLKAR dan PDI, terkecuali pemilu pertama Orde Baru yang diikuti oleh 10 Partai Politik. Perubahan jumlah partai politik peserta pemilu di Era Reformasi ini disebabkan oleh beberapa faktor, yaitu: pertama, persyaratan pendirian parpol yang terus diperbaharui dan diperketat melalui UU; kedua, penerapan ambang batas perolehan suara dari parpol pada pemilu (electoral threshold) yang menjadi salah satu persyaratan parpol dapat menjadi peserta pemilu berikutnya; dan ketiga, pemilih yang makin cerdas/rasional dalam menentukan pilihan.

Demokrasi merupakan sesuatu yang sangatlah penting, karena nilai-nilai yang dikandungnya sangat diperlukan sebagai pedoman untuk menata kehidupan berbangsa dan bernegara yang baik. Demokrasi merupakan alat yang dapat digunakan untuk mewujudkan masyarakat dan pemerintahan yang baik (good society and good government). Dalam sistem demokrasi, kekuasaan pemerintah dapat berasal dari rakyat baik secara langsung maupun perwakilan. Secara teoritis, peluang terlaksananya partisipasi politik dan partisipasi warga negara dari seluruh lapisan masyarakat terbuka lebar. 
Warga negara juga dapat melakukan kontrol sosial terhadap pelaksanaan pemerintahan karena posisi masyarakat adalah sebagai pemegang kedaulatan tertinggi.

Menurut ajaran Plato (Smith dkk, 1962:12) demokrasi dianggap hanyalah sebagai dunia ide dan bukan dunia nyata. Ada perbedaan yang terjadi antara das Sein dan das Solllen. Banyak negara modern pada saat ini menyatakan bahwa adalah negara demokrasi, tetapi pada kenyataannya terdapat perbedaan partisipasi rakyat dalam negara yang menamakan dirinya demokrasi tersebut. Demokrasi merupakan suatu bentuk atau mekanisme sistem pemerintahan suatu negara sebagai upaya mewujudkan kedaulatan rakyat (kekuasaan warga negara) atas negara untuk dijalankan oleh pemerintah negara tersebut.

Suatu negara dapat digolongkan warga negara yang mampu dan dapat melakukan permusyawaratan dalam negara dan non warga negara yang tidak dibolehkan ikut bermusyawarah seperti buruh dan anakanak. Buruh dan anak-anak dalam hal ini disamakan karena keduanya tidak mampu untuk melakukan tindakan politik dalam negara, karena masih memikirkan diri kebutuhan pokok masing-masing. Oleh sebab itu, demokrasi sebetulnya bukan ditentukan pada besarnya partisipasi rakyat, melainkan ditentukan oleh kualitas pengambil kebijakan negara. Oleh karena itu kualitas demokrasi tidak ditentukan oleh banyaknya orang yang mengambil keputusan negara melainkan ditentukan oleh kualitas orangorang yang mengambil keputusan negara. Untuk itu diperlukan adanya pembatasan terhadap orang-orang yang terlibat dalam pengambilan keputusan negara.

Agar suatu negara dapat mewujudkan demokrasi yang ideal, maka negara tersebut harus memiliki beberapa kriteria bagi pemerintahan yang baik, Robert A. Dahl mengatakan ada 5 kriteria demokrasi yang ideal antara lain (Robert A Dahl, 2001, 10-11), pertama, "Persamaan Hak Pilih", dimana dalam membuat keputusan kolektif yang mengikat, hak istimewa dari setiap warga negara seharusnya diperhatikan secara berimbang dalam menentukan keputusan terakhir. Kedua, "Partisipasi Efektif” yang berarti dalam seluruh proses pembuatan keputusan secara kolektif termasuk tahap penentuan agenda kerja, setiap warga negara harus mempunyai kesempatan yang sama dan memadai untuk menyatakan hak-hak istimewanya dalam rangka mewujudkan kesimpulan terakhir. Ketiga, "Pembeberan kebenaran" yang pada hakikatnya merupakan klimaks dari proses akuntabilitas publik yang terbuka dan transparan. Keempat, "Kontrol Terakhir Terhadap Agenda" dalam hal ini masyarakat seharusnya memiliki kekuasaan ekslusif untuk menentukan soal-soal mana yang harus dan tidak harus diputuskan melalui proses-proses yang memenuhi ketiga kriteria yang disebut pertama. Kelima, "Pencakupan" yang artinya masyarakat di sini harus meliputi semua orang dewasa dalam kaitannya dengan hukum, kecuali pendatang sementara. Pada hakekatnya, prinsip nilai-nilai demokrasi mampu mencegah tindakan pemerintah yang bersifat diskriminatif, karena pada dasarnya setiap warga negara memiliki kedudukan yang sama di depan hukum, ekonomi dan politik.

Berkaitan dengan hal tersebut, perlu diketahui bahwa pembubaran partai politik pada dasarnya diyakini sebagai sebuah mekanisme untuk melakukan pengawasan terhadap partai politik (Jimly Assiddiqie, 2005:128). Biasanya tindakan pembubaran partai politik merupakan tindak lanjut bagi partai politik yang melanggar suatu larangan yang telah ditentukan di dalam peraturan perundang-undangan atau konstitusi. Sebagai contoh adalah negara Pakistan, dalam Article 15 Political Parties Act 2002 (Undang-Undang tentang partai politik tahun 2002), menegaskan bahwa partai politik dapat dibubarkan jika terbukti (1) merupakan partai politik yang dibantu 
pendanaan kegiatannya oleh kekuatan asing, atau (2) terbukti bahwa proses pembentukan partai tersebut merugikan kedaulatan atau integritas wilayah negara, atau (3) terbukti mengadakan kegiatan yang merugikan kedaulatan atau integritas wilayah negara, atau (4) kegiatan partai politik tersebut terbukti terkait kejahatan terorisme (indulging in terorism) (Allan FG dam Harry SN, 2013: 12).

Laporan survei yang dilakukan oleh European Commission for Democracy through Law yang biasa disebut sebagai Venice Commision, mengenai pengaturan larangan dan tindakan pengawasan terhadap partai politik di 40 negara yang merespons pengisian 'questionnaire' yang diajukan (Ali Safaat, 2009:129), diperoleh kesimpulan bahwa: 1) Kegiatan partai politik dimanapun selalu dijamin atas dasar prinsip kebebasan berserikat (party activities everywhere are guaranted by the principle of freedom of association); 2) Secara umum terdapat kesamaan pandangan di semua negara bahwa terhadap partai politik yang tidak memenuhi ketentuan yang diatur dalam peraturan perundang-undangan yang berlaku dapat dijatuhi sanksi berupa tindakan pelarangan/pembekuan atau pembubaran (there is possibility to sanction political parties that do not respect a certain set of rules, through prohibition and dissolution of political parties, in number of countries which answered the questionnaire); 3) Prosedur yang berkenaan dengan tindakan pembatasan terhadap kegiatan partaipartai politik itu menunjukkan besarnya kepedulian dan tanggung jawab para pejabat yang berwenang di negara-negara yang bersangkutan dalam menghormati prinsipprinsip kebebasan berserikat (the procedure regarding measures restricting the activites of the political parties show the authorities' concern to respect the principle of freedom of association).

Tindakan pelarangan atau pembekuan kegiatan (prohibition), ataupun pembubaran (dissolution) partai politik dikenal juga di banyak negara di dunia, baik di negaranegara yang baru memraktikkan sistem demokrasi maupun negara-negara yang lebih dulu dari Indonesia. Sejarah Republik Indonesia pernah terjadi pembubaran partai politik oleh pemerintah tanpa melalui proses hukum bahkan tanpa adanya peran Lembaga peradilan sama sekali. Pembubaran model ini terjadi pada saat pembubaran PKI (Partai Komunis Indonesia) yang dilakukan berdasar pada KEPRRES No. XXV/MPRS/1996. Hal ini jika melihat peraturan saat itu maka tidak sesuai dengan PENPRES No. 7 Tahun 1959 akan tetapi berdasarkan Surat Perintah 11 Maret 1966. Hal ini dilakukan berdasarkan atas pertimbangan kondisi keamanan dan stabilitas negara Republik Indonesia.

Pembubaran partai politik dalam hal ini dimaksudkan sebagai ketentuan-ketentuan yang harus dipenuhi oleh partai politik, yang apabila dilanggar atau tidak dipenuhi, dapat menjadi dasar alasan partai politik tersebut dibubarkan. Di negara-negara eropa, berdasarkan hasil survey Venice Commission, terdapat beberapa alasan yang dapat menjadi dasar pembubaran, di antaranya adalah: (1) partai politik mempunyai tujuan yang bersifat "unlawful or immoral aims", (2) kegiatan partai membahayakan hak asasi manusia, bersifat totalitarian, serta bertentangan dengan prinsip-prinsip "rule of law and democracy", (3) merupakan partai ekstrim, (4) menyebarkan, mengajarkan, atau memperjuangkan kebencian, kekerasan, atau diskriminasi; (5) melakukan kegiatan dengan cara kekerasan yang anti demokrasi, (6) mengancam eksistensi dan kemerdekaan negara, (7) mengancam integritas wilayah negara, (8) menganjurkan kejahatan, (9) mengambil alih kegiatan negara; (10) melakukan kegiatan yang dilarang, dan (11) melakukan kegiatan "para-militer" (Safaat, 2009: 329-330).

Venice Commission juga merumuskan alasan yang dapat dijadikan dasar pembubaran partai politik, yaitu melakukan tindakan 
dengan menggunakan kekerasan sebagai alat politik untuk menjatuhkan tatanan demokrasi konstitusional sehingga meruntuhkan hak dan kebebasan yang dijamin konstitusi. Namun demikian, suatu partai politik tidak dapat dimintai pertanggungjawaban atas tindakan individu anggotanya yang tidak mendapatkan mandat dari partai. Selain itu, sebelum dilakukan pembubaran harus diupayakan tindakan lain yang kurang radikal untuk mencegah bahaya yang diakibatkan oleh partai politik tersebut.

Pada umumnya alasan pembubaran partai politik adalah karena pelanggaran terhadap larangan dan kewajiban partai politik. Hal itu misalnya dapat dilihat di Jerman, Turki, Bulgaria, dan negara-negara lain. Namun, selain alasan tersebut, beberapa negara juga menentukan bahwa pembubaran juga dapat terjadi apabila suatu partai politik gagal menjalankan aktivitasnya sebagai partai politik atau tidak lagi memenuhi persyaratan sebagai partai politik. Yang dimaksud dengan aktivitas dalam hal ini adalah aktivitas utama, yaitu mengikuti pemilihan umum dan menempatkan wakil di parlemen. Ketentuan-ketentuan tersebut dapat dijumpai di Korea Selatan, Hungaria, dan Moldova.

Berdasarkan Undang-Undang Nomor 2 Tahun 1999, Mahkamah Agung dapat membubarkan partai politik yang melakukan pelanggaran tertentu. Kewenangan itu dilakukan dengan terlebih dahulu mendengar keterangan dari Pengurus Pusat Partai Politik dan setelah melalui proses peradilan yang memiliki kekuatan hukum yang tetap. Dengan demikian, proses pembubaran partai politik oleh Mahkamah Agung berdasarkan Undang-Undang Nomor 2 Tahun 1999 harus melalui proses pengadilan untuk membuktikan pelanggaran yang dilakukan. Jika proses pengadilan tersebut telah diputus dan memperoleh kekuatan hukum tetap, dapat dilanjutkan dengan proses peradilan pembubaran untuk memeriksa keterangan dari pengurus partai pilitik yang bersangkutan. Bahkan sebelum proses peradilan pembubaran partai politik, Mahkamah Agung harus memberikan peringatan tertulis sebanyak 3 kali berturut-turut selama 3 bulan.

Undang-Undang Nomor 2 Tahun 1999 digantikan dengan Undang-Undang Nomor 31 Tahun 2002 di mana yang memutus pembubaran partai politik adalah Mahkamah Konstitusi sesuai dengan perubahan UUD NRI 1945. Ketentuan tentang pembubaran partai politik melalui proses pengadilan di Mahkamah Konstitusi juga diatur dalam Undang-Undang Nomor 24 Tahun 2003 tentang Mahkamah Konstitusi. Alasan pembubaran partai politik menurut UndangUndang Nomor 31 Tahun 2002 adalah jika pengurus partai politik menggunakan partainya untuk melakukan kegiatan menganut, mengembangkan dan menyebarkan ajaran atau paham Komunisme-Marxisme-Leninisme sehingga dituntut berdasarkan UndangUndang Nomor 27 Tahun 1999 Tentang Perubahan KUHP yang berkaitan dengan kejahatan terhadap keamanan negara. Sedangkan alasan yang ditentukan dalam Undang-Undang Nomor 24 Tahun 2003 adalah ideologi, asas, tujuan, program, dan kegiatan partai politik yang bertentangan dengan UUD 1945.

Berikut beberapa alasan-alasan yang dijadikan dasar dalam rangka melakukan pembubaran partai politik yang pernah terjadi di Indonesia pada rezim orde lama dan Rezim orde baru yang di ambil dari penelitian Disertasi M. Ali Safa'at: 
Tabel 1. Alasan Pembubaran Partai Politik pada masa Orde Lama

\begin{tabular}{|c|c|c|}
\hline Peraturan & Alasan dalam Peraturan & Alasan dalam Praktik \\
\hline $\begin{array}{l}\text { 1. Penpres No. } 7 \\
\text { Tahun } 1959 . \\
\text { 2. Perpres No. } 13 \\
\text { Tahun } 1960 . \\
\text { 3. Perpres } 25 \\
\text { Tahun } 1960 .\end{array}$ & $\begin{array}{l}\text { 1. Bertentangan dengan asas dan tujuan negara. } \\
\text { 2. Programnya bermaksud merombak asas } \\
\text { dan tujuan negara. } \\
\text { 3. Sedang melakukan pemberontakan karena } \\
\text { pemimpinnya turut serta dalam pemberontakan, } \\
\text { dan partai tidak dengan resmi menyalaHkan } \\
\text { perbuatan anggotanya itu. } \\
\text { Tidak memenuhi syarat sesuai syarat } \\
\text { pengakuan. }\end{array}$ & $\begin{array}{l}\text { Pembubaran Masjumi dan PSI } \\
\text { dengan alasan keterlibatan } \\
\text { pimpinan kedua partai tersebut } \\
\text { dalam pemberontakan PRRI/ } \\
\text { Permesta dan partai politiknya } \\
\text { tidak secara resmi menyalahkan } \\
\text { perbuatan anggotanya itu. }\end{array}$ \\
\hline
\end{tabular}

Tabel 2. Alasan Pembubaran Partai Politik pada Awal Orde Baru

\begin{tabular}{|c|c|c|}
\hline Peraturan & Alasan dalam Peraturan & Alasan dalam Praktik \\
\hline $\begin{array}{l}\text { 1) Penpres No. } 7 \text { Tahun } 1959 \\
\text { 2) Perpres No. } 13 \text { Tahun } 1960 . \\
\text { 3) Perpres } 25 \text { Tahun } 1960\end{array}$ & $\begin{array}{l}\text { 1. Bertentangan dengan asas } \\
\text { dan tujuan negara. } \\
\text { 2. Programnya bermaksud } \\
\text { merombak asas dan tujuan } \\
\text { negara. } \\
\text { 3. Sedang melakukan } \\
\text { pemberontakan karena } \\
\text { pemimpinnya turut serta } \\
\text { dalam pemberontakan, } \\
\text { dan partai tidak dengan } \\
\text { resmi menyalahkan } \\
\text { perbuatan anggotanya itu. } \\
\text { 4. Tidak memenuhi syarat sesuai } \\
\text { syarat pengakuan. }\end{array}$ & $\begin{array}{l}\text { Keppres No. 1/3/1966 tentang } \\
\text { Pembubaran PKI tidak berdasarkan } \\
\text { ketentuan yang saat itu berlaku. } \\
\text { Keppres tersebut dikuatkan dengan } \\
\text { Tap MPRS No. XXV/MPRS/1966. } \\
\text { 1. Alasan dalam Keppres No. 1/3/1966 } \\
\text { adalah munculnya aksi-aksi gelap } \\
\text { yang dilakukan oleh G } 30 \text { S/PKI } \\
\text { yang mengganggu kemanan rakyat } \\
\text { dan ketertiban. } \\
\text { 2. Alasan dalam Tap MPRS No. XXV/ } \\
\text { MPRS/1966 adalah bahwa ajaran } \\
\text { Komunisme/MarxismeLeninisme } \\
\text { bertentangan dengan Pancasila dan para } \\
\text { penganut paham tersebut, khususnya } \\
\text { PKI, telah terbukti beberapa kali } \\
\text { berusaha merobohkan kekuasaan } \\
\text { yang sah dengan jalan kekerasan. }\end{array}$ \\
\hline
\end{tabular}


Tabel 3. Alasan Pembubaran Partai Politik pada Masa Orde Baru

\begin{tabular}{|c|c|c|}
\hline Peraturan & Alasan dalam Peraturan & $\begin{array}{c}\text { Alasan } \\
\text { dalam Praktik }\end{array}$ \\
\hline $\begin{array}{l}\text { 1. UU No. } 3 \text { Tahun } 1975 \\
\text { 2. PP No. } 9 \text { Tahun } 1975\end{array}$ & $\begin{array}{l}\text { 1. Tidak mencantumkan asas Pancasila dan UUD } 1945 . \\
\text { 2. Tidak melaksanakan kewajiban Parpol melaksanakan, } \\
\text { mengamalkan, dan mengamankan Pancasila. } \\
\text { 3. Menganut, mengembangkan dan menyebarkan faham } \\
\text { atau ajaran Komunisme/Marxisme-Leninisme. } \\
\text { 4. Menganut, mengembangkan dan menyebarkan faham } \\
\text { atau ajaran lain yang bertentangan dengan Pancasila dan } \\
\text { UUD 1945 dalam segala bentuk dan perwujudannya. } \\
\text { 5. Menerima bantuan dari pihak asing. } \\
\text { 6. Memberikan bantuan kepada pihak asing yang mengikat } \\
\text { kepentingan bangsa dan negara. }\end{array}$ & \\
\hline $\begin{array}{l}\text { 1. UU No. } 3 \text { Tahun } 1985 \\
\text { 2. PP No. } 19 \text { Tahun } 1986\end{array}$ & $\begin{array}{l}\text { 1. Tidak mencantumkan Pancasila sebagai satu-satunya asas. } \\
\text { 2. Mencantumkan istilah atau pengertian lain yang dapat } \\
\text { mengurangi atau mengaburkan maksud ditetapkannya } \\
\text { Pancasila sebagai satu-satunya asas. } \\
\text { 3. Tidak melaksanakan kewajiban Parpol melaksanakan, } \\
\text { mengamalkan, dan mengamankan Pancasila. } \\
\text { 4. Menganut, mengembangkan dan menyebarkan faham } \\
\text { atau ajaran Komunisme/Marxisme-Leninisme. } \\
\text { 5. Menganut, mengembangkan dan menyebarkan faham } \\
\text { atau ajaran lain yang bertentangan dengan Pancasila dan } \\
\text { UUD 1945 dalam segala bentuk dan perwujudannya. } \\
\text { 6. Menerima bantuan dari pihak asing. } \\
\text { 7. Memberikan bantuan kepada pihak asing yang mengikat } \\
\text { kepentingan bangsa dan negara. }\end{array}$ & \\
\hline
\end{tabular}

Saat ini ketentuan-ketentuan laranganlarangan terhadap tindakan yang tidak semestinya dilakukan oleh partai politik yang apabila dilanggar maka partai politik tersebut akan mendapatkan sanksi telah secara jelas diatur di dalam Pasal 40 UU No 2. Tahun 2008 jo UU No. 2 Tahun 2011 tentang Partai Politik. akan tetapi jika kita melihat dari pengaturan dari berbagai negara termasuk dalam sejarah pengaturan partai politik di Republik Indonesia, maka pokok dari alasan yang digunakan untuk membubarkan partai politik adalah hal-hal substansial tentang ideologi, pertahanan, keamanan dan stabilitas negara. Yang pada dasarnya ketentuan pengaturan dan kualifikasinya selalu didasarkan pada kepentingan negara sehingga politik hukum pembentukan aturannya dapat berubah-ubah.

Kenyataannya sekarang, secara formal tidak ada lagi partai politik di Indonesia yang berani melawan ideologi Pancasila, UUD NRI 1945, dan NKRI. Fakta di lapangan justru menunjukkan bahwa sebenarnya bentuk-bentuk pelanggaran yang dilakukan oleh partai politik lebih kepada pelanggaran yang sifatnya tidak diatur oleh undang-undang. Padahal tindakan yang dilakukan oleh partai politik tersebut secara jelas telah melanggar peraturan perundang-undangan, merusak eksistensi nilai-nilai demokrasi, dan berdampak negatif terhadap penyelenggaraan negara. Sebagai contoh adalah saat partai politik melakukan pelanggaran dalam penyelenggaraan pemilu. Mengingat begitu pentingnya pemilu bagi negara demokrasi, dan pemilu yang jujur, fair serta bersih merupakan instrumen penting dalam mewujudkan pemilu yang demokratis di Indonesia, upaya memperluas permohonan pembubaran partai politik dengan menjadikan pelanggaran pemilu sebagai salah satu alasan terhadap usul pembubaran partai politik di Indonesia menjadi suatu keharusan yang tidak dapat dinafikkan. Dengan begitu, secara sadar negara telah melangkahkan kakinya menuju sistem pemilu yang lebih demokratis. 
Jika kita melihat Pasal 40 ayat (2) huruf a UU Partai Politik, Partai Politik dilarang melakukan kegiatan yang bertentangan dengan UUD NRI 1945 dan peraturan perundang-undangan. hal ini menjadi sangat luas makna penafsirannya karena apakah sebuah partai politik di daerah yang dalam proses pemilihan umum melakukan sebuah kecurangan "money politic" dapat menjadi alasan pembenar atas adanya pemenuhan unsur-unsur kejahatan yang dapat menjadi alasan pembenar dalam pembubaran partai politik.

Jika melihat pengaturan partai politik di Philippina, di mana partai politik yang terdaftar dan memiliki kursi di parlemen berhak atas bantuan pendanaan dari negara untuk operasional kegiatan pengembangan partai dan sosialisasi pada pemilu, namun hak tersebut juga melekatkan kewajiban yaitu adanya laporan pertanggungjawaban atas penggunaannya kepada negara. Jika terdapat penyalahgunaan dan/atau tidak memenuhi kewajiban maka partai politik dapat dibubarkan oleh negara.

Adanya berbagai macam formulasi pengaturan terhadap partai politik pada prinsipnya dibuat untuk melindungi kepentingan masyarakat. Akan tetapi, maksud yang baik tersebut tidak akan dapat terwujud jika dalam pengaturannya tidak rigid dan spesifik sehingga akan banyak celah yang digunakan sebagai alasan pembenar dari partai politik untuk dapat membantah segala tindakan yang telah dilakukan yang dapat diindikasikan telah memenuhi kualifikasi pelanggaran dan layak untuk dibubarkan. Serta dibutuhkan institusi yang memang kredibel dan objektif menjalankan fungsi kontrol dan pengawasan terhadap partai politik.

\section{Ius Constituendum Pembubaran Partai Politik di Indonesia}

Pengaturan partai politik di suatu negara dipengaruhi oleh kecenderungan hukum nasional yang menempatkan partai politik, apakah lebih sebagai organisasi privat atau publik. Hal itu juga terkait dengan paradigma pengaturan partai politik yang dianut. Paradigma managerial, progresif dan Pluralist, cenderung menempatkan partai politik sebagai organisasi publik yang perlu diatur oleh negara. Sedangkan paradigma libertarian dan political market, lebih memposisikan partai politik sebagai organisasi privat, sehingga hukum negara tidak terlalu banyak mengatur (Safaat, 2009: 85).

Pembubaran suatu partai politik adalah penghilangan status badan hukum partai politik sebagai organisasi yang utuh, dari pusat hingga daerah. Muncul permasalahan jika pelanggaran tersebut hanya dilakukan oleh pengurus tingkat daerah, apakah dapat diajukan pembubaran untuk daerah tertentu saja atau juga dapat menjadi alasan pembubaran keseluruhan organisasi. Mengingat bahwa badan hukum adalah suatu tata hukum tersendiri (partial legal order) (Kelsen, 1971:190-191) yang mengikat dari pusat hingga satuan terkecil, maka subyek hukum yang berhubungan dengan hukum negara adalah badan hukum yang diwakili oleh pengurus puncaknya, atau pengurus pusat. Sedangkan organisasi partai politik di tingkat daerah adalah bagian dari badan hukum partai politik yang berhubungan secara hierarkis dengan pengurus tingkat pusat. Jika partai politik di tingkat daerah melakukan tindakan hukum tertentu, harus dilihat sebagai organ badan hukum yang mewakili kepentingan partai politik secara keseluruhan.

Hal-hal yang dapat menjadi alasan pembubaran partai politik dalam peraturan perundang-undangan di masa yang akan datang tentu lebih baik jika ditentukan dengan cara lebih detail, berdasarkan tujuan pengaturan pembubaran partai politik, yaitu untuk melindungi konstitusi, yang di dalamnya termasuk melindungi demokrasi dan ideologi negara, kedaulatan negara, dan keamanan nasional. Pada bagian sebelumnya telah diuraikan prinsip-prinsip dasar yang 
harus dipatuhi oleh partai politik dan jika dilanggar menjadi alasan pembubaran di berbagai negara.

Untuk dapat dibubarkannya suatu partai politik, pelanggaran-pelanggaran yang memenuhi alasan pembubaran tidak hanya merupakan tindakan perseorangan pengurus atau anggota partai politik, tetapi pelanggaran yang dilakukan oleh partai politik sebagai organisasi. Paling tidak harus dibuktikan bahwa partai politik telah dengan sengaja membiarkan pengurus atau anggota tertentu menggunakan organisasi partai politik untuk melakukan pelanggaran yang dapat mengakibatkan pembubaran.

Saat ini sesuai dengan Undang-Undang Mahkamah Konstitusi yang memiliki legal standing atau kedudukan sebagai pemohon dalam proses pembubaran Partai Politik adalah Pemerintah. Namun, jika suatu partai politik dinilai oleh Pemerintah telah melanggar Undang-Undang Dasar dan/ atau peraturan perundang-undangan yang berlaku, maka adalah tanggung jawab pemerintah untuk mengambil inisiatif guna membubarkan partai politik yang bersangkutan menurut prosedur hukum yang berlaku. Namun pertanyaan yang kemudian muncul adalah, bagaimana jika ternyata justru partai politik pemerintah lah yang bermasalah? tentu akan menimbulan potensi conflict of interest antara pemerintah dan partai politik bersangkutan yang berujung pada "ketidakmungkinan" pemerintah mengambil inisiatif untuk mengusulkan pembubaran terhadap partai politiknya sendiri. Apabila itu benar terjadi, tentu hal ini menciderai nilai-nilai demokrasi yang ada di Indonesia.

Kemungkinan yang dapat muncul adalah jika pemerintah menggunakan kewenangan yang dimilikinya sebagai pemohon pembubaran partai politik dengan maksud untuk menghilangkan partai politik yang berseberangan dengan pemerintah dengan memaksakan dan mengkaitkan tindakan-tindakan yang dilakukan oleh partai politik lawan supaya dinyatakan sebagai sebuah tindakan yang memenuhi unsur-unsur dari larangan partai politik yang berujung pada pembubaran. Hal ini dirasa sangat perlu adanya sebuah perluasan pihakpihak yang memiliki legal standing dalam permohonan pembubaran partai politik.

Standing merupakan satu konsep yang digunakan untuk menentukan apakah satu pihak terkena dampak secara cukup sehingga satu perselisihan diajukan ke depan pengadilan. Yurisprudensi Amerika Serikat dikatakan bahwa ada tiga syarat yang harus dipenuhi untuk mempunyai standing to sue, yaitu: (1) adanya kerugian yang timbul karena adanya pelanggaran kepentingan pemohon yang dilindungi secara hukum yang bersifat spesifikasi atau khusus, aktual dalam satu kontroversi dan bukan hanya bersifat potensial, (2) adanya hubungan sebab akibat atau hubungan kualitas antara kerugian dengan berlakunya satu undang-undang, (3) kemungkinan dengan diberikannya keputusan yang diharapkan, maka kerugian akan dihindarkan dan dipulihkan (Siahaan, 2006:81).

Apabila mengacu pada ketiga syarat tersebut, maka dapat ditarik kesimpulan bahwa di dalam perkara pembubaran partai politik seharusnya rakyat juga mempunyai hak untuk menggugat atau bertindak sebagai pemohon, karena rakyat juga dirugikan atas pelaksanaan kegiatan partai politik yang dapat menghambat kesejahteraan umum. Kepentingan masyarakat dan negara harus menjadi prioritas, partai politik yang dibentuk dengan maksud dan tujuan salah satunya sebagai penyambung antara negara dengan rakyat harus sebagaimana mestinya. Masyarakat sebagai pemilik kedaulatan berhak untuk ikut melakukan pengawasan dan kontrol kepada Partai Politik. 


\section{SIMPULAN}

1. Pemberian kewenangan kepada rakyat dalam mekanisme pembubaran Partai Politik memperhatikan rakyat sebagai pemilik kadaulatan negara. Rakyat sudah selayaknya dapat dikualifikasian sebagai pihak-pihak yang memiliki legal standing permohonan pembubaran partai politik, hal ini karena jika tetap mengacu pada pemohon tunggal dari pemerintah akan memiliki potensi adanya conflict of interest dari pemerintah dan partai politik. Karena pada dasarnya pemerintahan dibentuk oleh partai politik atau gabungan partai politik sehingga akan sangat sukar jika pemohon dan termohon merupakan bagian yang tidak terpisahkan.

\section{DAFTAR RUJUKAN}

Amal, Ihlasul Amal. 1996. Teori-Teori Mutakhir Partai Politik, Edisi Kedua. Yogyakarta: Tiara Wacana.

Abdul Barie Azed dan Makmur Amir. 2013. Pemilu dan Partai Politik di Indonesia. Jakarta. Pusat Studi Hukum Tata Negara FH UI.

Artani Hasbi. 2001. Musyawarah \& Demokrasi, Analisis Konseptual Aplikatif dalam Lintasan Sejarah Pemikiran Politik Islam. Jakarta. Gaya Media Pratama.

Allan F.G Wardhana \& Harry Setya Nugraha. 2013. Pemberian Legal Standing kepada Perseorangan atau Kelompok Masyarakat dalam Usul Pembubaran Partai Politik. Jurnal Ius Quia Iustum Nomor 4 Volume 20.

. 2013. Revitalisasi Peran Warga Negara dalam Pengawasan terhadap Partai Politik: Pemberian Legal Standing Kepada Perseorangan atau Kelompok Masyarakat dalam Usul Pembubaran Partai Politik. Karya Tulis. Fakultas Hukum Universitas Islam Indonesia.

Agustino, Leo. 2007. Perihal Ilmu Politik.
2. Ius Constituendum pembubaran partai politik di Indonesia menjadi sebuah model sanksi yang sesuai terhadap partai politik yang dibuktikan dan diputuskan oleh lembaga yang berwenang dalam hal ini lembaga yudisial bahwa partai politik telah melanggar ketentuan. Di mana rumusan ketentuaan-ketentuan tersebut dibentuk berdasarkan kondisi dan politik hukum masing-masing negara, yang pada intinya dimaksudkan untuk melindungi segala kepentingan masyarakat, bangsa dan negara. Sehingga jika terdapat partai politik yang melanggar akan diberikan sanksi yang tegas dengan dibubarkannya partai politik tersebut.

Yogyakarta. Graha Ilmu.

Aprista Ristyawati. 2017. Analisis Hukum Mengenai Legal Standing Pemohon dalam Perkara Pembubaran Partai Politik di Indoensia sebagai Wujud Negara Remokratis. Tesis Program Magister Ilmu Hukum Universitas Diponegoro.

Association For Democratic Reform. 2011. The Political Parties (Registration and Regulation of Affairs, etc), https:// www.adrindia.org/sites/default/files/ Bill\%20on\%20pol\%20parties.pdf . New Delhi.

Jimly Assiddiqie. 2004. Konstitusi \& Konstitusionalisme Indonesia. Jakarta. Kerjasama MK RI dan Pusat Studi HTN FHUI, . Kemerdekaan

Berserikat Pembubaran Partai Politik dan Mahkamah Konstitusi. Jakarta. Konstitusi Press, 2005. 1994. Gagasan Kedaulatan Rakyat Dalam Konstitusi dan Pelaksanaannya di Indonesia. Jakarta. PT. Ichtiar Baru Van Hoeve. . Pengantar Ilmu Hukum Tata Negara. Jakarta. Raja Grafindo Persada. 
2010.

Barnett, Hilaire. 2004. Constitutional \& Administrative Law, Fifth Edition, London-Sydney-Portland Orengon. Cavendish Publishing Limited.

Bagir Manan. 2011. "Kedaulatan Rakyat, Hak Asasi Manusia dan Negara Hukum", dalam Jurnal Konstitusi PSHK-FH Universitas Islam Indonesia. Vol. IV No.2.

Budiarjo, Miriam. 1985. Dasar-Dasar Ilmu Politik. Jakarta. PT. Gramedia.

Dahl, Robert A. 2001. Perihal Demokrasi Menjelajahi Teori dan Praktik Demokrasi Secara Singkat. Jakarta. Yayasan Obor Indonesia. . 1982. Dilemas of pluratist democracy, autonomy vs control, Yale University Press.

Diane Revitch \& Abigail Thernstrom (ed) (ed). 2005. Demokrasi Klasik \& Modern-Tulisan Tokoh-tokoh Pemikir Ulung Sepanjang Masa. Yogyakarta. Yayasan Obor Indonesia.

Field, G. Lowell. 1951. Government in Modern Society. New York. Toronto. London. McGraw - Hill Book Company, Inc.

Fahmi, Khairul. 2010. Prinsip Kedaulatan Rakyat dalam Penentuan Sistem Pemilihan Anggota Legislatif. Jurnal Konstitusi Vol. 7 Nomor 3.

Fajar Iswahyudi. 2012. Efektivitas Partisipasi Masyarakat dalam Perbaikan Pelayanan Publik. Jurnal Borneo Administrasi Volume 8 No. 3.

Ghaisani, N, R. 2018. Partai Politik di Prancis. (sumber) https://prezi. com/dgz27mxhrvjf/partai-politikdi-perancis/.

H. Salim HS dan Erlies Septiana Nurbani. 2014. Penerapan Teori Hukum pada Penelitian Disertasi dan Tesis. Jakarta. Rajawali Pers.

Huntington, Samuel P. 2003. Tertib Politik di Tengah Pergeseran Kepentingan Masa. Judul asli: Political Order in Chganging Societies, diterjemahkan oleh Sahat Simamora dan Suryatmi, Jakarta. PT. Raja Grafindo Persada. Harjono. 2008. Konstitusi Sebagai Rumah Bangsa Pemikiran Hukum. Jakarta. Sekretariat Jenderal dan Kepaniteraan Mahkamah Konstitusi.

Hakim, Abdul Aziz. 2011. Negara Hukum dan Demokrasi di Indonesia. Yogyakarta. Pustaka Pelajar.

HR. Ridwan. 2013. Hukum Administrasi Negara. Jakarta. PT Raja Grafindo Persada.

Hidjaz, Kamal. 2010. Efektivitas Penyelenggaraan Kewenangan Dalam Sistem Pemerintahan Daerah Di Indonesia. Makasar: Pustaka Refleksi.

Italy Constitution, (sumber) http://www. oefre.unibe.ch/law/icl/Italy\%20\%20 Constitution.htm.

Laski, Harold J. 1951. A Grammar of Politic. Eleventh Impression, London, Goerge Allen \& Unwin Ltd.

Issacharoff, Samuel. 2012. Fragile Democracies Constested Power in the Era of Constitusional Courts, Constitusional Law at New York University School of Law.

I-CONnect. 2018. Do All Democracies Need Party Dissolution Mechanisms?. (sumber) http://www.iconnectblog. com/2016/06/do-all-democraciesneed-party-dissolution-mechanisms/ .

JJ. von Smith, Grot Denker over staat and Recht diterjemahkan oleh Wiratno dan Djamluddin Dt. Singo Mangkuto. 1962. Ahli-ahli Pemikir Besar tentang Negara dan Hukum. Jakarta. Pembangunan.

Maclver, RM. 1955. The Modern State. First Edition London. Oxford University Press.

Mahkamah Konstitusi. 2010. Hukum Acara Mahkamah Konstitusi. Cetakan pertama. Jakarta. Sekretariat Jenderal dan Kepaniteraan MKRI.

Mamora, Sahatsi. 1985. Dilema Demokrasi Pluralis antara Otonomi dan Kontrol. Jakarta. CV Rajawali. 
Myron Weiner dan Joseph Lapalombara. 1996. The Impact of Parties on Political Development. New York. Princenton University Press.

Muarar, Siahaan. 2006. Hukum Acara Mahkamah Konstitusi Republik Indonesia. Jakarta. Mahkamah Konstitusi Republik Indonesia.

Muhammad Sukroni. 2015. Gagasan Perluasan Legal Standing dalam Permohonan Pembubaran Partai Politik Di Indonesia. JOM Fakultas Hukum Vol II Nomor 1.

Moh. Shaleh. 2011. Akibat Hukum Pembubaran Partai Politik Oleh Mahkamah Konstitusi, Jurnal Konstitusi Kerjasama antara MK RI dengan Pusat Kajian Konstitusi Fakultas Hukum Universitas Narotama Surabaya. Vol I No.1.

Nurtjahjo, Hendra. 2006. Filsafat Demokrasi, Jakarta. Bumi Aksara.

Nur Hidayat dan Sardini Gunawan. 2016. "60 Tahun Jimly Asshiddiqie: Menurut Para Sahabat". Jakarta. Yayasan Pustaka Obor Indonesia.

Pamungkas, Sigit. 2012. Partai Politik, Teori dan Praktek di Indonesia. Edisi Revisi, Yogyakarta. Institute Democracy and Welfarism.

Projodikoro, Wirjono. 1981. Asas-Asas Ilmu Negara dan Politik. Catatan Ke-2, Bandung. PT. Eresco Jakarta.

Peraturan Mahkamah Konstitusi No. 12 tahun 2008 tentang Prosedur Beracara dalam Pembubaran Partai Politik

Putusan Mahkamah Konstitusi Republik Indonesa Nomor : 53/PUU-IX/2011

Rousseau, Jean Jacques. 2007. Du Contract Social (Perjanjian Sosial). Jakarta. Visimedia.

Ridlwan, Zulkarnain. 2012. Mekanisme Konsultasi Publik: Instrumen Pembangun Good Governance di Daerah. Jurnal Hukum Universitas Lampung Volume 6 No. 3.

Richard H. Pildes. 2004. The Constitutional of Democratic Politic. Hardvad Law Review. Vol. 118:1.

Republik Indonesia, Undang-Undang Dasar Tahun 1945

Republik Indonesia, Undang-Undang Nomor 2 Tahun 2011 tentang Perubahan atas Undang-Undang Nomor 2 Tahun 2008

Tentang Partai Politik; LN RI Tahun 2011 Nomor 8; TLN RI Nomor 5189.

Republik, Indonesia. Undang-Undang Nomor

8 Tahun 2011 Tentang Perubahan atas

Undang-Undang Nomor 24 Tahun 2003 tentang Mahkamah Konstitusi.

LN RI Tahun 2011 Nomor 70. TLN RI Nomor 5226.

Republik Indonesia, Undang-Undang Nomor 2 Tahun 2008 tentang Partai Politik; LN RI Tahun 2008 Nomor 2; TLN RI Nomor 4801.

Republik, Indonesia. Undang-Undang Nomor 31 Tahun 2002 tentang Partai Politik; LN RI Tahun 2002 Nomor 138; TLN RI Nomor 4251.

Republik, Indonesia. Undang-Undang Nomor 24 Tahun 2003 Tentang Mahkamah Konstitusi. LN RI Tahun 2003 Nomor 98; TLN RI Nomor 4316.

Republik, Indonesia. Undang-Undang Nomor 2 Tahun 1999 tentang Partai Politik. LN RI Tahun 1999 Nomor 22; TLN RI Nomor 3809.

Safa'at, Muchamad Ali. 2011. Pembubaran Partai Politik: Pengaturan dan Praktik Pembubaran Partai Politik dalam Pergulatan Republik. Jakarta. Raja Grafindo Persada.

Santoso (Ed.), Kholid O. 2009. Mencari Demokrasi Gagasan dan Pemikiran. Bandung. Sega Arsy.

Sinclair, Barbara. 1988. Do Parties Matter? Center for The Study of Democracy. Irvine. University of California.

Siti Zuhro, Lilis Mulyani, Fitria. 2010. Kisruh Peraturan Daerah: Mengurai Masalah dan Solusinya. Yogyakarta. Penerbit Ombak.

Soemantri, Sri. 1981. Perbandingan Hukum 
Tata Negara. Jakarta. Jakarta. Rajawali.

Surbakti, Ramlan. 1992. Memahami Ilmu Politik. Jakarta. PT. Gramedia Sarana Indonesia.

Suseno, Franz Magnis. 1999. Etika Politik: Prinsip-Prinsip Moral Dasar Kenegaraan Modern. Cetakan kelima. Jakarta. PT. Gramedia Pustaka Utama. Symonides, Janusz. 2000. Human Right: Concept and Standart. AldershotBurlington USA-Singapore-Sydney. UNESCO Publishing.

Sam. Issacharoff. 2006. "Fradile Democracies". New York University Public las and Legal Theory Working Papers, Paper 40.

Spain Constitution. 1992. ICL Documen Status 29 Dec 1978, Consolidated up to amendment. The 1987 Constitution of the Republic of the Philippines. (sumber) http://www.oefre.unibe. ch/law/icl/kons-Phil.doc.
Spain Constitution. ICL Documen Status 29 Dec 1978. Consolidated up to amendment 27 August 1992 (sumber) http://www.oefre.unibe.ch/law/icl/ kons-Spain.htm.

The Lawphil Project. Republic Act No. 7941. (sumber) https://www.lawphil.net/ statutes/repacts/ra1995/ra_7941_1995. html.

The Political Party Development Act of 2007. (sumber) https://www.senate. gov.ph/lisdata/68965654!.pdf.

Usman, Wan. 2003. Daya Tahan Bangsa. Jakarta. Program Studi Ketahanan Nasional Universitas Indonesia.

Woll, Peter. 1986. Constitutional Democracy Second Ediition. Boston-Toronto. Little, Brown and Company.

Widayati. 2011."Pembubaran Partai Politik Dalam Sistem Ketatanegaraan Indonesia. Jurnal Hukum Universitas Islam Sultan Agung. Volume. XXVI. Nomor. 2. 